\title{
Two types of resumptive pronouns in polish relative clauses
}

\section{Citation}

Szczegielniak, Adam. 2005. "Two Types of Resumptive Pronouns in Polish Relative Clauses." Linguistic Variation Yearbook 5 (1) (January 1): 165-185. doi:10.1075/livy.5.06szc. http:// dx.doi.org/10.1075/livy.5.06szc.

\section{Published Version}

doi:10.1075/livy.5.06szc

\section{Permanent link}

http://nrs.harvard.edu/urn-3:HUL.InstRepos:11880355

\section{Terms of Use}

This article was downloaded from Harvard University's DASH repository, and is made available under the terms and conditions applicable to Other Posted Material, as set forth at http:// nrs.harvard.edu/urn-3:HUL.InstRepos:dash.current.terms-of-use\#LAA

\section{Share Your Story}

The Harvard community has made this article openly available.

Please share how this access benefits you. Submit a story.

\section{Accessibility}


In: Linguistic Variation Yearbook Vol. 5. Benjamins. 165-185, 2005, Pierre Pica, Johan Rooryck and Jeroen Van Craenenbroeck (eds.) Benjamins.

\title{
Two Types of Resumptive Pronouns in Polish Relative Clauses*
}

\author{
Adam Szczegielniak \\ Harvard University/Boston College
}

This paper discusses two types of resumptive pronouns found in Polish relative clauses: (i) adjacent resumptives and (ii) embedded resumptives. It will be argued that adjacent resumptives are truncated forms of the relative operator, whereas embedded resumptives are 'regular' resumptive pronouns found in other languages like Hebrew and Russian. Support for this claim will come from analyzing the differences between adjacent and embedded resumptives, and analyzing the similarities between adjacent resumptives and relative operators. Cross-linguistic data involving the interaction of relative clause formation and resumption, as well as the interaction of cliticization and resumption will provide additional support for the above claim.

Keywords: resumptive pronouns, relative clauses, cliticization

\footnotetext{
*I would like to thank Noam Chomsky, David Pesetsky, Cedric Boeckx, and the anonymous reviewer for their invaluable comments. I would also like to thank Pierre Pica for his infinite patience. The judgments in reported here are mine and that of two other speakers of standard Polish, and one speaker of standard Russian.
} 


\section{Introduction}

In this paper I will discuss the properties of resumptive pronouns in Polish relative clauses. It will be argued that Polish has 'regular' embedded resumptive pronoun constructions, like those found in Hebrew, Russian, and English. However, it will be also shown that Polish has another type of resumptive pronoun, only present in one type of relative clause. It will be argued that this resumptive pronoun is in fact a truncated form of the relative operator. The paper will concentrate on constructions like the one below:

$$
\begin{aligned}
& \text { Marysia zna chłopców, co ich Ania lubi } \\
& \text { Mary knows boys that them Anne likes } \\
& \text { 'Mary knows some boys that Ann likes' }
\end{aligned}
$$

What is interesting about (1) is that the resumptive pronoun is adjacent to the relative marker (Mykowiecka 2000, Fisiak 1978, Pesestky 1998). This configuration is only possible in relative clauses headed by a complementizer like relative marker: $c o$, but not in relative clauses headed by an operator: który. ${ }^{1}$ Consider the example below:

\section{*(2) Marysia zna chłopców, których ich Ania lubi Mary knows boys whom them Anne likes 'Mary knows some boys who Ann likes'}

\footnotetext{
${ }^{1}$ I will discuss briefly the differences between both types of relative clauses later in the paper. For a full discussion and arguments for considering który to be an operator see Szczegielniak (2005). The operator który is inflected for number/gender/case/person and can be translated as 'which'. The marker $c o$ is not inflected and is a homonym of 'what' in Polish.
} 
However, resumptive pronouns are possible in który-relatives. They just have to be embedded. When embedded, resumptives are possible in both types of relative clauses:

a. Marysia zna chłopców, których ja wiem że (ich)
Mary knows boys whom I know that (them)
Ania lubi
Anne likes
'Mary knows some boys who I know Ann likes'

b. Marysia zna chłopców, co ja wiem że (ich) Ania

Mary knows boys that I know that (them) Anne

lubi

likes

'Mary knows some boys that I know that Ann likes'

I will call resumptive pronouns that can occur next to the relative marker pronouns adjacent resumptives as opposed to embedded resumptives, which require embedding in Polish and other languages (see Borer 1984, Erteschik-Shir 1992, Boeckx 2003).

It will be proposed that adjacent resumptive pronouns are actually truncated/cliticized forms of the operator który. Thus constructions like (4a) have the underlying form of $(4 b) .^{2}$

\footnotetext{
${ }^{2}$ As pointed out by an anonymous reviewer, Pesetsky (1998) following Fisiak et.al. (1978) reports that resumptive pronouns in co-relatives are impossible in subject position, and when they carry accusative case. The former claim is correct, and I will provide an account why this is so in section 4. However, the claim that accusative resumptives in co-relative clauses are
} 


\author{
a. Marysia zna chłopców, co ich Ania lubi \\ Mary knows boys that them Anne likes \\ 'Mary knows some boys that Ann likes'
}
b. Marysia zna chłopców, co których Ania lubi
Mary knows boys that whom Anne likes
'Mary knows some boys that Ann likes'

This I will argue that constructions involving adjacent resumptives involve operator movement (matching analysis Sauerland 1998, Szczegielniak

marginal is due to an example where the resumptive pronoun is in the wrong position. Consider the example from Pesetsky (1998:374):

*(i) Ten samochód co Janek go widział wczoraj zniknął this car that Janek it saw yesterday disappeared

'This car that Janek saw yesterday disappeared'

Adjacent resumptives, however, require adjacency to the relative marker co. Hence, (ii) is perfectly fine:

(ii) Ten samochód co go Janek widział wczoraj zniknął this car that it Janek saw yesterday disappeared

'This car that Janek saw yesterday disappeared'

The ungrammaticality of (i) stems from the Focus/Topic restrictions that allow the subject to be sandwiched between two relative markers. I will argue that (i) is ungrammatical since it is derived from (iii) which is also ungrammatical (see hypothesis 5 below).

*(iii) Ten samochód co Janek którego widział wczoraj zniknął this car that Janek which saw yesterday disappeared

'This car that Janek saw yesterday disappeared' 
2005), which is subsequently followed by truncation of the wh-part of the operator. $^{3}$

(5) Adjacent resumptives are truncated operators derived by the elimination of the wh-component.

In the section below, I will discuss resumption in Polish in more detail and show that embedded resumptives and adjacent resumptives have different properties. In section 3, I compare the properties of relative clauses with adjacent resumptives and relative clauses with both co and który markers in order to show that the former is derived from the latter (the hypothesis in 5). In section 4, I examine the morphological operation of relative pronoun truncation. In section 5, I provide an account of the difference between Russian and Polish as far as adjacent resumptives are concerned.

\section{Resumption in Polish}

In Polish, both co and który relatives allow embedded resumptive pronouns, both in subject and object relative clauses (the slash between co and który indicates 'either or').

(6) a. Chłopiec co/który Marysia powiedziała, że on $_{\boldsymbol{i}}$

Boy that/which Mary said that he wyszedł jest przystojny

left is handsome

'A boy that Mary said left is handsome'

\footnotetext{
${ }^{3}$ Note however that the proposal here is compatible with other analyses of relative clause formation, for example Kayne (1994).
} 
b. Chłopiec $\mathrm{c}_{\mathrm{i}} \mathbf{c o} / \mathbf{k}$ tórego Marysia powiedziała, że ja znam Boy that/which Mary said that I know $\boldsymbol{g o}_{\boldsymbol{i}}$ dobrze jest przystojny him well is handsome 'A boy that Mary said that I know him is handsome'

Embedded resumptives in Polish are not limited to relative clauses. They can occur in A-bar movement constructions like wh-movement or Topicalization. Consider examples below:

(7) a. [Który komputer $]_{1}$ Marek podejrzewał że Maria wie że Which computer Mark suspected that Mary knows that Jan chce $\boldsymbol{g o}_{1}$ kupić?

Jan wants it buy

'Which computer did Mark suspect that Mary knows that John wants to buy'

b. $\quad[\text { Ten komputer }]_{1}$ Marek podejrzewał że Maria wie że This computer Mark suspected that Mary knows that Jan chce go $_{1}$ kupić

Jan wants it buy

'This computer Mark suspected that Mary knows that John wants to buy'

Another property of embedded resumptives is that they can alleviate Island Constraints. Consider the following CED violations (Huang 1982): 
Two Types of Resumptive Pronouns in Polish Relative Clauses

(8) ?a. [Jakiego obrazu $]_{1}$ ja zadzwoniłem do Marii po jego

Which painting I called to Mary after it

namalowaniu?

painting

'*Which painting I called to Mary after painting it'

*b. [Jakiego obrazu $]_{1}$ ja zadzwonilem do Marii po

Which painting I called to Mary after

namalowaniu $\mathrm{t}_{1}$ ?

painting

‘*Which painting I called to Mary after painting’

Unlike in co-relative clauses, in both wh-movement and Topicalization constructions embedding is crucial for resumptive pronouns to be present.

(9) *a. [Który komputer $]_{1}$ Marek go $\boldsymbol{g o}_{1}$ kupił?

Which computer Mark it bought

'Which computer Mark bought'

*b. [Ten komputer $]_{1}$ Marek go $\boldsymbol{g o}_{1}$ kupił

Which computer Mark it bought

'This computer Mark bought'

The above discussion shows that embedded resumptives are not limited to relative clause constructions in Polish. However, resumption in these other types of A-bar movement can only be carried out via one type of resumption that involves embedded resumptives. 
The above data strongly suggests that resumptive pronouns adjacent to the relative marker $c o$ are not the same pronouns that we find in embedded resumptive constructions. Following the hypothesis in (5), I propose that adjacent resumptives are clitic/truncated forms of the relative marker który and that adjacent pronoun constructions are derived from co plus który constructions (see $4 a$ and $4 b$ ).

An alternative hypothesis accounting for adjacent resumptives involves resumptive pronoun climbing. This would mean that adjacent resumptives are underlyingly embedded resumptives that have undergone raising. Aside from the issue of explaining why resumptive climbing would be only possible in object co-relatives ${ }^{4}$, and why it is impossible in który-relatives, one would have to also account for the fact that resumptives cannot climb in non-relative clause contexts. Hence, resumptive climbing in wh or Topicalization constructions is not possible. Consider the examples in (9), and those below where I there is enough embedding for potential climbing to occur:

*a. [Który komputer $]_{\mathrm{i}} \mathbf{g o}_{\mathbf{i}}$ Marek myśli że Maria wie że Which computer it Mark thinks that Mary knows that Jan chce kupić $\mathrm{t}_{\mathrm{i}}$ ?

Jan wants it buy

'Which computer does Mark think that Mary knows that John wants to buy'

*b. [Ten komputer $]_{\mathrm{i}} \mathbf{g o}_{\mathbf{i}}$ Marek myśli że Maria wie że Jan

\footnotetext{
${ }^{4}$ It is not the case that in Polish only object pronouns can undergo movement. Consider the example below involving contrastive Focus (underlining indicates stress): 
This computer it Mark thinks that Mary knows that Jan chce kupić $\mathrm{t}_{\mathrm{i}}$ wants buy

'This computer Mark thinks that Mary knows that John wants to buy'

Another piece of evidence supporting the claim that adjacent resumptives are different from embedded resumptives comes from the restrictions on cliticization/truncation. Polish relative clauses can have the operator as a complement of a PP. Both the operator and PP have to be fronted (Polish does not allow preposition stranding). In cases when an inflected relative marker heads the relative clause, the PP is before it. When an uninflected relative marker heads the relative clause, the PP requires a pronoun complement (both fronted or in-situ). In constructions where the relative is introduced by both co and który, the PP is sandwiched between them. Consider the examples below:

(11) a. Ja widze chłopca do którego ty przemowiłeś

I see boy to whom you spoke

'I see a boy to whom you spoke'

b. Ja widze chłopca co do niego ty przemowileś

I see boy that to him you spoke

'I see a boy to whom you spoke'

c. Ja widze chłopca co ty przemowileś do niego

I see boy that you spoke to him

'I see a boy to whom you spoke' 
d. Ja widze chłopca co do ktorego ty przemowiłeś I see boy that to whom you spoke 'I see a boy to whom you spoke'

Interestingly, resumptives that are PP complements cannot take the clitic form (12a,b), whereas adjacent resumptives cannot take the full pronominal form $(12 \mathrm{c}, \mathrm{d})$. In contrast, embedded resumptives can take the full pronoun form (12e). Consider the following contrasts:

*a. Ja widze chłopca co do niego ty przemowiłeś

I see boy that to him you spoke

'I see a boy to whom you spoke'

b. Ja widze chłopca co do niego ty przemowiłeś

I see boy that to him you spoke

'I see a boy to whom you spoke'

?c. Ja widze chłopca co jego ty lubisz

I see boy that him you like

'I see a boy that you like'

d. Ja widze chłopca co jego ty lubisz

I see boy that him you like

'I see a boy that you like'

e. Ja widze chłopca co Jurek wie że ty jego lubisz

I see boy that Jurek knows that you him like 
'I see a boy that Jurek knows that you like him'

Furthermore, there is no resumptive doubling. Hence, in 'co plus który' relatives an embedded resumptive and adjacent one are not possible if they have to be part of a PP. However, their co-occurrence is less marginal in non PP contexts. Consider the examples below:

*a. Ja widze chłopca co do niego Maria wiedziała że on I see boy that to him Mary knew that he chciał byś ty do niego przemowił wanted that you to him spoke 'I see a boy to whom Mary knew that he wanted you to speak'

?b. Ja widze chłopca co go Maria powiedziała że tyś chciał I see boy that him Mary said that you wanted by go poznać

to meet him

'I see a boy whom Mary said that you wanted to meet

I will argue that cliticization/truncation is not possible in PP complements. I propose that resumptives that follow a PP are embedded resumptives that can raise to the highest clause via XP movement. Since there are no adjacent resumptives in PP constructions, doubling is not possible. Only one token of each type of resumptive is possible in a clause. Example (13b) is 
more acceptable than (13a) since each pronoun is an instance of a different resumptive. The top one is an adjacent resumptive, the lower one an embedded resumptive.

There are two predictions that the cliticization/truncation hypothesis makes. First, adjacent resumptives should not be possible in co plus który relatives. This is because adjacent resumptives are truncated forms of the operator który. This turns out to be correct:

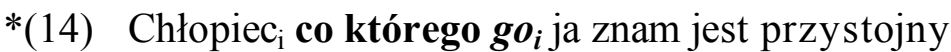
Boy that which him I know is handsome 'A boy that I know him is handsome'

However, embedded resumptives should be possible in co plus który relatives since embedded resumptives are not truncated forms of the operator który. This turns out also to be correct:

Chłopiec $_{\mathrm{i}}$ co którego Marysia chce bym $\boldsymbol{g o}_{\boldsymbol{i}}$ poznał jest Boy that which Mary wants that him meet is przystojny

handsome

'A boy that Mary wants me to meet is handsome'

Secondly, the hypothesis predicts that adjacent resumptives and embedded resumptives can be both present in a single clause (this is basically example (13b) repeated below as $(16)):^{5}$

\footnotetext{
${ }^{5}$ The embedded pronoun is inverted with the verb and the embedded subject is deleted here in order to make a difficult construction more acceptable. Polish is a pro-drop language and clitic pronouns do not 'like' to follow verbs. Until now, I have kept them in their canonical order for exposition purposes and thus the judgments were more marginal than in (16).
} 
Two Types of Resumptive Pronouns in Polish Relative Clauses

?(16) Chłopiec co $_{\mathrm{g}} \boldsymbol{g o}_{\mathbf{1}}$ Marysia chce bym $\boldsymbol{g o}_{\boldsymbol{i}}$ poznał jest przystojny Boy that which Mary wants that him meet is handsome 'A boy that Mary wants me to meet is handsome'

It would be hard to explain examples where we have multiple instances of the same resumptive. However, if we assume that the above example is actually derived from (15) then the re-occurrence of the resumptive is no longer a mystery. Note that if multiple resumptives are in fact instances of two different kinds of resumptives, then cases where there are more than two resumptives, one embedded and one adjacent, should be unacceptable. This turns out to be correct:

??(17) Chłopiec $_{\mathrm{i}}$ co go $_{\boldsymbol{i}}$ ja wiem że $\boldsymbol{g o}_{\boldsymbol{i}}$ Marysia powiedziała, że go Boy that him I know that him Mary said that him znam jest przystojny know is handsome 'A boy that I know that Mary said that I know him is handsome'

One final difference between embedded and adjacent resumptives comes from the fact that there are no subject adjacent resumptives whereas embedded resumptives can be both subject and object pronouns (see also McCloskey 1978 for similar data in Irish). Consider the following contrasts: ${ }^{6}$

18. a. Marysia zna chłopców $_{1}$, co ich $\boldsymbol{h}_{1}$ ja lubie

\footnotetext{
${ }^{6}$ In section 4 I will provide an account why there are no subject adjacent resumptives. It will be argued that this is a result of lack of remaining nominative morphology after truncation.
} 
Mary knows boys that them I like

'Mary knows some boys that I like'

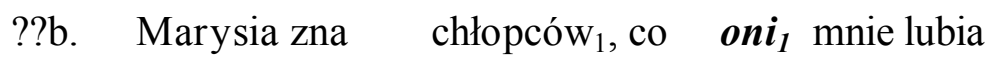
Mary knows boys that they me like

'Mary knows some boys that like me'

c. Marysia zna chłopców ${ }_{1}$, co Ja wiem że Jurek powiedział że Mary knows boys that I know that Jurek said that $\boldsymbol{o n i}_{1}$ mnie lubia

they me like

'Mary knows some boys that I know that Jurek said that they like me'

If adjacent resumptives were to be derived from embedded resumptives, the lack of subject adjacent resumptives would be hard to account for. Note that subject pronouns in Polish can undergo climbing (footnote 4). Thus the subject/object contrast cannot be captured by assuming that subject embedded pronoun cannot raise to a higher clause.

In this section I have shown that adjacent resumptives and embedded resumptives are two different kinds of resumptive pronouns. In the next section, I will show that relative clauses with adjacent resumptives behave like relative clauses that contain both co and który relative markers. 


\section{Relative clauses with adjacent resumptives compared to co plus który relatives}

Before I explore the similarities between co-relative clauses with adjacent resumptives and relative clauses containing the marker $c o$ and the operator który, let me examine the evidence that który is actually a relative pronoun and an operator. I will do this by examining the ability of head noun interpretation inside the relative clause in relative clauses that have który as a relative marker (with or without $c o$ ) and relative clauses that do not have it.

Following Szczegielniak (2005), I assume that Polish has two types of relative clauses: (i) derived via a head noun raising analysis; (ii) derived via operator movement and adjunction to the head noun (see also Borsley 1997 and Mykowiecka 2000, and Szucsich 2003 for a slightly different view). The type of derivation roughly corresponds to the type of relative marker used. Relative clauses headed by a relative complementizer $c o$ can be derived via head noun raising. Relative clauses headed by the relative pronoun który can only be derived via operator movement and adjunction to the head noun. ${ }^{7}$

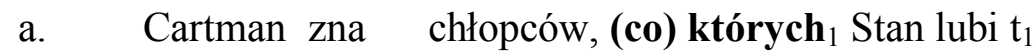
Cartman knows boys that who Stan likes 'Cartman knows some boys who Stan likes'

b. Cartman zna chłopców $_{1}$, co Stan lubi $\mathrm{t}_{1}$ Cartman knows boys that Stan likes 'Cartman knows some boys that Stan likes

\footnotetext{
${ }^{7}$ The relative marker $c o$ is never inflected for anything in its role as a relative marker. It is also used exclusively in non-complement relative clauses. Complement relatives, as well as subordinate clauses utilize the complementizer $\dot{z} e$. In Polish, a comma before the relative marker does not indicate an appositive reading.
} 
Following Szczegielniak (2005), I propose the following generalization how relative clauses in Polish are derived:

(20) Raising Analysis (Sauerland 1998, Szczegielniak 2005)

$\mathrm{HN}_{1} \quad\left[\mathrm{RC}\right.$ co $\left.\left[\mathrm{vP} \mathrm{V}\left[\mathrm{DP} \mathrm{HN}_{1}\right]\right]\right]$

(21) Adjunction/Matching Analysis (Sauerland 1998, Szczegielniak 2005)

$\mathrm{HN}_{1}\left[\mathrm{RC}(\mathrm{co}) \mathrm{który}_{1}[\mathrm{vP} \mathrm{V}\right.$ [DP który 1$\left.]\right]$

It will be argued that relative clauses where both markers are present behave identically to relative clauses where the który relative pronoun is present. ${ }^{8}$

(22) Cartman zna chłopców ${ }_{1}$, co których Stan lubi $t_{1}$ Cartman knows boys that which Stan likes 'Cartman knows some boys that Stan likes

\footnotetext{
${ }^{8}$ Constructions with both markers present are not restricted to any specific dialects or registers.
} 
Two Types of Resumptive Pronouns in Polish Relative Clauses

Evidence in support for such a claim comes from a battery of semantic and syntactic tests.

(23) Evidence for head noun reconstruction in co-relatives and lack of head noun reconstruction in który-relatives (following Szczegielniak 2005)

\begin{tabular}{|c|c|c|c|c|c|c|c|}
\hline $\begin{array}{l}\text { Type/ } \\
\text { Behav- } \\
\text { ior }\end{array}$ & $\begin{array}{l}\text { Apposi- } \\
\text { tive } \\
\text { reading }\end{array}$ & $\begin{array}{l}\text { Degree } \\
\text { reading }\end{array}$ & $\begin{array}{l}\text { Idioms } \\
\text { inside } \\
\text { the } R C\end{array}$ & $\begin{array}{l}\text { Condition } \\
-C \\
\text { violation }\end{array}$ & $\begin{array}{l}\text { Reflexive } \\
\text { interpreta } \\
\text {-tion } \\
\text { inside } \\
\text { relative }\end{array}$ & $\begin{array}{l}\text { Wide } \\
\text { and } \\
\text { narrow } \\
\text { Scope }\end{array}$ & $\begin{array}{l}\text { Relative } \\
\text { behaves } \\
\text { as an } \\
\text { adjunct }\end{array}$ \\
\hline Co & $x$ & $\sqrt{ }$ & $\checkmark$ & $\checkmark$ & $\sqrt{ }$ & $\sqrt{ }$ & $x$ \\
\hline Który & $\checkmark$ & $x$ & $x$ & $x$ & $x$ & $x$ & $\checkmark$ \\
\hline
\end{tabular}

According to Szczegielniak (2005), co-relatives do not allow an appositive reading, but do allow degree/amount readings (Carlson 1977), allow the breaking up idioms, induce Condition C-violations (the head noun reconstructs and induces a Condition $\mathrm{C}$ violation), allow the interpretation of a reflexive inside the relative clause, allow wide scope of the head noun, finally the relative does not behave as adjunct in co-relative clauses. In contrast, któryrelatives exhibit the opposite behavior that indicates that the head noun cannot be interpreted inside the relative clause. Take for example the breaking up of idioms. Idioms can be relativized in co-relatives, but not in który-relatives:

(24) a. Słów co on nie rzucał na wiatr words that he not throw on wind 'Empty promises that he did not make'

??b. Słów których on nie rzucał na wiatr words which he not throw on wind 
'Empty promises that he did not make'

??c. Słów co których on nie rzucał na wiatr words that which he not throw on wind 'Empty promises that he did not make'

Following Szczegielniak (2005), I will assume that co plus który relatives behave like który-relatives. Both types of relative clauses behave in way that indicates that the head noun is not interpreted inside the relative clause (see 21). Hence, we observe: (i) the ability of head nouns to 'escape' Condition $\mathrm{C}$ effects, (ii) the ability of a given relative clause to license a restrictive meaning, and (iii) the inability to license a degree reading (for a full list see 23).

In the reminder of this section it will be shown that constructions with adjacent resumptives and co plus który relatives behave identically as far as the interpretation of the head noun is concerned. I will explore the ability to license appositive readings, the ability to escape Condition $\mathrm{C}$ effects, and the inability to license degree readings of co plus który and adjacent resumptive pronoun constructions. It will be shown that co plus który and adjacent resumptive pronoun constructions pattern together as far as head noun reconstruction in contrast to $c o$-relative clauses that do not have an operator.

Chierchia and McConnell-Ginet (1990) argue that appositive relative clauses are background assertions, and authors such as Emonds (1979), Sells (1985), Demirdache (1991), Del Gobbo (2003) have shown that appositive relative clauses are independent sentences. Co plus który constructions allow both a restrictive and appositive reading. The example below shows that this is also the case in adjacent pronoun constructions. A relative clause with $c o$ and 
an adjacent pronoun can license an appositive reading as well as a restrictive one. This can be contrasted with the bare co relative in example (b) where a non-restrictive reading is not possible (I use proper names to force an appositive reading).

(25) a. Maria, co którą Janek poznał, poszła do domu Maria that which Janek met went to home 'Mary, who Janek met, went home'

b. Maria, co ja Janek poznał, poszła do domu Maria that her Janek met went to home 'Mary, who Janek met, went home'

*c. Maria, co Janek poznał, poszła do domu Maria that her Janek met went to home 'Mary, who Janek met, went home'

The above examples support the claim that (25a) is actually derived from (25b) and that both constructions are derived via operator movement (see example 21), as opposed to (25c) which has to be derived via head noun raising (Szczegielniak 2005).

Constructions involving Condition $\mathrm{C}$ violations are another good indicator of whether head noun reconstruction had taken place or not. The Rexpression 'John' can 'escape' a Condition C violation in co plus który constructions. This is also true for adjacent resumptive constructions, but not 
for bare co relatives (i.e. relatives without any kind of resumptive pronoun). Consider the examples below: $:^{9,10}$

a. Znam koleżankę $J a n k a_{1}$ co ktorą $\left(o n_{1}\right)$ powiedział że Know friend (fem) $\mathrm{John}_{1}$ that which he 1 said that chce polubić wants like

'I know a friend of John that he said that he wants to like'

b. Znam koleżankę $J a n k a_{1}$ co $j q \quad\left(o n_{1}\right)$ powiedzał że chce Know friend (fem) John 1 that her he ${ }_{1}$ said that wants polubić

like

'I know a friend of John that he said that he wants to like'

??c. Znam koleżankę Jank $a_{1}$ co $\quad\left(o n_{1}\right)$ powiedział że chce Know friend (fem) $J_{0 h n}$ that he ${ }_{1}$ said that wants polubić

like

'I know a friend of John that he said that he wants to like'

\footnotetext{
9 The binding condition judgments are tricky for some speakers. It seems that there is possibility for some speakers of Polish to have a null operator like in English.

${ }^{10} \mathrm{I}$ have put the subject pronoun in parenthesis since Polish is a pro-drop language and dropping the subject makes the construction more natural.
} 
Condition $\mathrm{C}$ effects provide support to the claim that the head noun in co plus który and adjacent resumptive relatives can be interpreted outside the $\mathrm{RC}$, whereas relative clauses containing just co seem to force head noun reconstruction. This in turn supports the claim that (26a) is derived from (26b) and that example (26c) is derived in a different fashion (head noun raising).

A third example where we see head noun reconstruction not taking place is in cases where a degree reading is not possible. Carlson (1977) was the first to observe that relatives can have degree/amount readings in addition to restrictive ones. Degree/amount relative clauses behave differently from regular restrictive relative clauses. Degree relatives indicate the degree of quantity, not identity of substance. For example in English, we have the following contrast (Grosu and Landman 1998, following Heim 1997):

(27) a. It will take us the rest of our long lives to drink the champagne that/Ø they spilled that evening

b. It will take us the rest of our long lives to drink the champagne which they spilled that evening

Example (27a) can be a restrictive relative or a degree/amount relative. In the latter case, we get identity of quantity and not of substance. Authors like Carlson (1977), Sauerland (1998), Heim (1997), Grosu and Landman (1998) have argued that in order to have a degree/amount reading the part of the DP 'champagne' that depicts the amount of champagne has to be in some way interpreted inside the RC. I will assume that in order to arrive at a degree reading, the head noun has to be interpreted inside the relative clause. 
Polish relative clauses containing co plus który allow for an identity reading only (Szczegielniak 2005). This is also true for relative clauses containing adjacent resumptives, but not for relative clauses headed just by $c o$ :

(28) ??a. Całe życie nam zajmię wypić tyle szampana, co

whole life us take drink this much champagne that

który oni rozlali tego wieczoru

which they spilled this evening

'It will take us our whole life to drink all the champagne

that they spilled this evening'

??b. Całe życie nam zajmię wypić tyle szampana, co $\quad \boldsymbol{g o}_{\boldsymbol{I}}$ whole life us take drink this much champagne that it oni rozlali tego wieczoru they spilled this evening 'It will take us our whole life to drink all the champagne that they spilled this evening'

c. Całe życie nam zajmię wypić tyle szampana, co whole life us take drink this much champagne that oni rozlali tego wieczoru they spilled this evening 
'It will take us our whole life to drink all the champagne that they spilled this evening'

The degree reading data clearly indicates that head noun reconstruction is not only optional, but probably impossible in both co plus który and adjacent resumptive constructions. This again supports the claim in (5) that (28b) is derived from (28a) and that (28c) has a different derivation.

The above facts indicate that co plus który relative clauses and relative clauses with adjacent resumptives pattern in the same way as far as head noun reconstruction is concerned. However note that non-adjacent resumptive pronoun constructions behave identically to adjacent resumptive constructions and co plus który relatives in that they: (i) do not allow degree readings; (ii) permit the escape of Condition $\mathrm{C}$ effects; and (iii) license appositive meanings. Consider the following examples:

(29) a. Maria 1 co Janek wie że $j \boldsymbol{q}_{1}$ poznał wczoraj poszła Maria that Janek knows that her met yesterday went do domu to home 'Mary, who Janek knows that he met her, went home'

b. Znam [koleżankę $\left.J a n k a_{1}\right]_{2}$ co $o n_{1}$ powiedzał że chce ja Know friend(fem) $\mathrm{John}_{1}$ that he $\mathrm{I}_{1}$ said that wants her polubić

like 
'I know a friend of John that he said that he wants to like'

??c. Całe życie nam zajmie wypić tyle szampana 1 , co whole life us take drink this much champagne that Jan widział jak go $_{1}$ oni rozlali tego wieczoru Jan saw how it they spilled this evening 'It will take us our whole life to drink all the champagne that they spilled this evening'

However, as I have shown in previous sections, adjacent resumptives cannot be considered identical to regular resumptives. Evidence that adjacent resumptives are different from other resumptives comes from: (i) differences between adjacent and embedded resumptives: adjacent resumptives are only possible in object co relatives, whereas embedded resumptives and are possible in co, który and co and który subject and object relative clauses, (ii) cooccurrence of adjacent and embedded resumptives in contrast to the impossibility of two adjacent or two embedded resumptives co-occurring in the same clause, and (iii) the fact that in non-relative clause contexts only embedded resumptives are possible. Thus, I argue that adjacent resumptives are clitic/truncated forms of the relative operators. ${ }^{11}$

\section{Relative pronoun truncation}

In order to establish a more comprehensive picture of how adjacent resumptives are formed, I will explore the morpho-phonological relationship between the resumptive pronoun form and the który relative pronoun. As can

\footnotetext{
${ }^{11}$ It is not a mystery why embedded resumptives would block head noun reconstruction in $c o$ relative clauses. As was shown earlier, embedded resumptives alleviate island effects, thus it is likely that reconstruction is blocked in constructions containing embedded resumptives.
} 
be seen, there is a strong relationship between the two as far as form is concerned. In most cases, a straightforward elimination of the [+wh] element któr is sufficient to arrive at the form of the resumptive pronoun. The form of both adjacent and embedded resumptives is identical. Only in [+nom] forms do they differ in that there are no nominative adjacent resumptive pronouns. Coincidentally, the nominative forms are the only ones that cannot be directly derived from the form of the relative pronoun. ${ }^{12}$

(30) The form of resumptive pronouns and of the relative pronoun który

$\begin{array}{lll}\text { a. } & \text { Singular Masc } & \\ \text { Case } & \text { rel pronoun } & \text { resumptive } \\ \text { NOM } & \text { który } & \text { on/zero in adjacent resumptives } \\ \text { ACC } & \text { którego } & \text { go } \\ \text { GEN } & \text { którego } & \text { go } \\ \text { DAT } & \text { któremu } & \text { mu } \\ \text { INST } & \text { którym } & \\ \text { LOC } & \text { którym } & \text { nim } \\ \text { b. } & \text { Singular Fem } & \\ \text { Case } & \text { rel pronoun } & \text { resumptive } \\ \text { NOM } & \text { która } & \text { ona/ zero in adjacent resumptives } \\ \text { ACC } & \text { która } & \text { ja } \\ \text { GEN } & \text { której } & \text { jej } \\ \text { DAT } & \text { której } & \text { jej/niej } \\ \text { INST } & \text { która } & \text { nia }\end{array}$

\footnotetext{
12 The addition of $/ \mathrm{n} /$ or $/ \mathrm{j} /$ to a pronoun is a frequent process in Slavic languages. The alternation between /i/ and / $\mathrm{y} /$ is also very common in Polish (see Rubach 1984).
} 


$\begin{array}{llll}\text { LOC } & \text { której } & \text { jej/niej } & \\ \text { c. } & \text { Plural Masc/Fem } & \\ \text { Case } & \text { rel pron } & \text { resumptive } & \\ \text { NOM } & \text { którzy/które(f)oni/one(f)/ zero in adjacent } \\ & & & \text { resumptives } \\ \text { ACC } & \text { których } & \text { (n)ich } & \\ \text { GEN } & \text { których } & \text { (n)ich } & \\ \text { DAT } & \text { którym } & \text { nim } \\ \text { INST } & \text { którymi } & \text { nimi } \\ \text { LOC } & \text { których } & \text { nich }\end{array}$

The above examples indicate that in many cases we can clearly derive the form of the resumptive pronoun from the relative pronoun. ${ }^{13}$ Crucially, we can now account for the fact that there are no subject-adjacent resumptives. This is because Nominative case marked on który has no overt pronominal

\footnotetext{
${ }^{13}$ Unfortunately, there are examples where there is no clear correlation between the form of the resumptive and the relative pronoun (David Pesetsky p.c.). For example, the second person singular head noun 'you':
}

(i) Ty którego ja widziałem you(nom) whom I saw

'You whom I saw'

(ii) $\mathrm{Ty}_{1} \quad$ co ciebie $_{1} \quad$ ja widziałem

you(nom) that you(acc) I saw

'You that I saw'

The transformation from którego to ciebie is obviously not a transparent morphological process. 
part, and after deleting the $w h$ part there is nothing left. Note that this correctly predicts that Dative subjects will have an adjacent resumptive:

a. Znam dziewczynę ${ }_{1}$ co $\mathbf{j e j}_{\mathbf{1}} \quad$ się Marek
know girl that her(DAT) refl Mark (ACC)
podoba
likes
'I know a girl that likes Mark'

??b. Dziewczyna 1 co ona 1 poszła do domu jest piękna girl that she went to home is beautiful 'A girl that went home is beautiful'

I assume that cliticization/truncation of który takes place after the relative pronoun has raised out of its base position. This can be seen in examples where the relative pronoun is in-situ and is in its full form.

?(32) Kobietę [RC mężczyzna rozpoznał którą wczoraj] Janek woman(acc) man (nom) recognized which yesterday Janek zna od lat knows for years

'A woman who a man recognized yesterday Janek knows for years' 
In fact, cliticization has to take place after który raising since it will be argued that the element któr- triggers obligatory raising of the relative pronoun in co plus który relatives, and optional raising in który relatives. This would account for the contrast between (33a) and (33b), where it seems that in co plus który relatives the cliticized form can stay in situ, but not the full form. ${ }^{14}$

a. Kobietę [co mężczyzna rozpoznał ja $a_{1}$ wczoraj] woman(acc) that man(nom) recognized her yesterday

Janek zna od lat

Janek knows for years

'A woman who a man recognized yesterday Janek knows for years'

*b. Kobietę [co mężczyzna rozpoznał którą

wczoraj]

woman(acc)that man(nom) recognized whose yesterday Janek zna od lat

Janek knows for years

\footnotetext{
${ }^{14}$ The (b) example improves if the material between co and który is focused. However, this would then imply a derivation where there is movement into the space between the two relative markers and not który remaining in situ. Obviously, this also leaves the question why the operator when not accompanied by co can remain in-situ as in (34).
} 
'A woman who a man recognized yesterday Janek knows for years'

I argue therefore that adjacent resumptives are clitic forms of the który relative pronoun in co plus który constructions, and cliticization takes place after the relative pronoun has raised out of its base position.

\section{Cross-linguistic predictions - the case of Russian}

There is a prediction that in languages where there are two ways of introducing a relative clause but no possibility of combining them, there should be no adjacent resumptive pronouns. This arguably could be the case in English, but Russian offers a more persuasive example. Russian has čto relatives (equivalent of co relatives) and has kotoryj relatives (the equivalent of który relatives, see Szczegielniak 2005):

(34) a. Sobaka, čto guljala vo dvore, byla golodnaja.

Dog that walked in yard was hungry

'The dog that walked in the yard was hungry'

b. Sobaka, čto my našli včera, byla golodnaja.

Dog that we found yesterday was hungry

'The dog we found yesterday was hungry'

(35) a. Sobaka, kotoraja guljala vo dvore, byla golodnaja.

Dog which walked in yard was hungry

'The dog that walked in the yard was hungry' 
b. Sobaka, kotoruju my našli včera, byla golodnaja.

Dog which we found yesterday was hungry

'The dog we found yesterday was hungry'

Russian also has embedded subject and object resumptive pronouns with both čto and with kotoryj relatives. However, there are no adjacent pronouns.

(36) a. Sobaka 1 , čto /kotoraja on skazal čto my dumali čto

Dog that/which he said that we thought that $\boldsymbol{o n a}_{1}$ byla golodnaja, guljala vo dvore

she was hungry walking in yard

'The dog that he said that we thought that she was hungry was walking in the yard'

*b. Sobaka $a_{1}$ čto/kotoraja $\boldsymbol{o n a}_{1}$ on skazal čto byla golodnaja, Dog that/which she he said that was hungry guljala vo dvore. walking in yard 'The dog that he said was hungry was walking in the yard'

c. Sobaka $a_{1}$, čto/kotoruju on skazal čto my dumali čto Dog that/which he said that we thought that 
my $\boldsymbol{e} \ddot{\boldsymbol{e}}_{1}$ nakormili, byla snova golodnaja.

we it fed was again hungry.

'The dog that he said that we thought we had fed it was hungry again'

*d Sobaka ${ }_{1}$, čto/kotoruju $\boldsymbol{e}_{\boldsymbol{e}}$ on skazal čto my nakormili, Dog that $/$ which it he said that we fed byla snova golodnaja. was again hungry 'The dog he said that we fed was hungry again'

This correlates with the fact that in Russian there are no čto plus kotoryj relative clauses:

*a. Sobaka, čto kotoraja guliala vo dvore, byla golodnaja. Dog that which walked in yard was hungry 'The dog that walked in the yard was hungry'

*b. Sobaka, čto kotoruju my našli včera, byla golodnaja. Dog that which we found yesterday was hungry 'The dog we found yesterday was hungry'

Thus in Russian because there are no čto plus kotoryj relative clauses then there are no adjacent relative pronouns since there is nothing to cliticize next to čto. If adjacent resumptives were derived via movement of an embedded pronoun this difference between Polish and Russian would be a mystery. Especially if we adopt the proposal that the two types of Russian relatives are derived in the same way as Polish ones. 


\section{Conclusion}

In this paper I have shown that adjacent resumptive pronoun constructions in Polish co-relative clauses are derived from relative clauses containing both the relative marker co and the relative operator który. Adjacent resumptives are a product of truncation of the wh-element of the operator. This explains the identical behavior of relative clauses with adjacent resumptives and co plus który relative clauses. It accounts for the fact that there are no object adjacent resumptive pronouns and for cases of multiple resumption. Finally the proposal put forward here accounts for the lack of adjacent resumptives in Russian čto-relative clauses.

\section{References}

Boeckx, Cedric. 2003. Islands and Chains. Amsterdam: Benjamins. 
Borer, Hagit. 1984. Restrictive relatives in Modern Hebrew. Natural Language \& Linguistic Theory 2, 219-260.

Borsley, Robert D. 1997. Relative Clauses and the Theory of Phrase Structure. Linguistic Inquiry 28:629-647.

Carlson, Greg. 1977. Amount Relatives. Language 53:520-542.

Chierchia, Gennaro and Sally McConnell-Ginet. 1990. Meaning and Grammar. Cambridge, MIT: MIT Press.

Demirdache, Hamida. 1991. Resumptive chains in restrictive relatives, appositives and dislocation structures. MIT Doctoral Dissertation.

Erteschik-Shir,nNomi. 1992. Resumptive pronouns in islands. Island Constraints, ed. by Helen Goodluck and M. Rochemont, 89-108. Dortrecht: Kluwer.

Emonds, Joseph. 1979. "Appositive relatives have no properties." Linguistic Inquiry 10. 211-243.

Fisiak, Jacek, Maria Lipińska-Grzegorek, Tadeusz Zabrocki. 1978. An Introductory English-Polish Contrastive Grammar. Warsaw. Państwowe Wydawnictwo Naukowe

Gobbo, Francesca Del. 2003. Appositives at the interface, University of California, Irvine. Doctoral Dissertation.

Grosu, Alexander, and Landman, Fred. 1998. Strange Relatives of the Third Kind. Natural Language Semantics 6:125-170.

Heim, Irene. 1997. Predicates or Formulas? Evidence from Ellipsis. Proceedings from Semantics and Linguistic Theory 7:197-221.

Huang, Cheng-Teh James. 1982. Logical relations in Chinese and the theory of grammar. MIT Doctoral Dissertation.

Mykowiecka, Agnieszka. 2000. Polish Relative Pronouns. Paper presented at Proceedings of the General Linguistics in Poland Conference, Warsaw.

McCloskey, James. 1978. A Fragment of a Grammar of Modern Irish. Linguistics, MIT Doctoral Dissertation. Published as Texas Linguistic Forum 11.

Pesetsky, David. 1998. "Some Optimality Principles of Sentence Pronunciation." Is the Best Good Enough? ed. by Pilar Barbosa, et. al., 337-385. MIT Press, Cambridge MA.

Rubach, Jerzy. 1984 .Cyclic and Lexical Phonology. The Structure of Polish. Dordrecht: Forris

Sauerland, Ulrich. 1998. On the making and meaning of chains. MIT Doctoral Dissertation.

Sells, Peter. 1985. Restrictive and non-restrictive modification. CSLI Report. Stanford, CA: Stanford University.

Szczegielniak, Adam. 2005. Relativization that you did .... Harvard Doctoral Dissertation. MIT Occasional Papers in Linguistics vol. 24.

Szucsich, Luka. 2003. "The structure of Relative Clauses in Slavic." 
Adam Szczegielniak

Investigations into Formal Slavic Linguistics ed. by Peter Kosta, et. al. vol. II, 697-714. 